\title{
Analysis of Secondary School Students' Attitudes and Self-Efficacy Perceptions towards Physical Education and The Sports Course
}

\author{
Gökhan Arıkan ${ }^{1, *}$ \\ ${ }^{1}$ School of Physical Education and Sports, Harran University, Şanlıurfa, Turkey \\ *Correspondence: School of Physical Education and Sports, Harran University, Şanlıurfa, Turkey. Tel: \\ 90-532-636-3661. E-mail: arikangokhan@hotmail.com
}

Received: August 27, 2020

Accepted: November 16, 2020

Online Published: December 10, 2020

doi:10.5430/wje.v10n6p14

URL: https://doi.org/10.5430/wje.v10n6p14

\begin{abstract}
This study aimed to analyze attitudes and self-sufficiency perceptions of students from different license of sports and students with no sports branches at the secondary school level towards the physical education and sports course. Education should not be based solely on the increased or widespread use of written sources, images, and technological tools and equipment. It is a process in which students are involved in social, mental, and sports activities. However, great emphasis is given to physical education and sports, which have a direct and indirect effect on their physical, mental, emotional and social development, within educational activities. The study included 255 students (120 female, 135 male) studying at two different secondary schools in Şanlıurfa (Vatan secondary school with a sports facility and Ziyaeddin Akbulut secondary school without a sports facility) during the 2019-2020 academic year, and the Physical Education Predisposition Scale was used in the study. The scale is comprised of 11 items. It consists of two factors, namely 'Attitude' (6 items) and 'Self-Efficacy' (5 items). A significant difference between these schools was found based on the findings obtained from this scale. When the results were examined according to the gender variable, it was found that there was a significant difference between male students and female students in terms of the total scale dimension. Again, a significant result in favor of males was found in terms of self-efficacy dimension scores. In terms of sports branches, a significant difference was found between students who are licensed athletes and those who are not. However, no statistical difference was found when examined in terms of the family profession group. According to the attitude dimension results, there was a significant difference between students engaged in basketball and students engaged in handball as well as students without a branch and students engaged in handball. According to the results of the self-efficacy dimension, there was a significant difference between students without a branch and students engaged in basketball as well as those without a license and those engaged in handball. According to our findings, it is thought that the significant difference between the license is related to the reflection of the attitudes of physical education teachers in schools onto the students.
\end{abstract}

Keywords: physical education, attitude, self-efficacy, sports, secondary school

\section{Introduction}

Education should not be based solely on the increased or widespread use of written sources, images, and technological tools and equipment. It is a process in which students are involved in social, mental, and sports activities

However, great emphasis is given to physical education and sports, which have a direct and indirect effect on their physical, mental, emotional and social development, within educational activities. Because the basis of sports is constantly desiring success, and to continue moving forward when faced with difficulties (Togo et al.,2018). When examined as an attitude, it has been explained that people are not born with attitudes but rather attitudes are learned by experience, and that certain attitudes are learned by experience while others are developed due to other factors (Kağıtçıbaşı, 2005).

In a similar, Güllü et al. (2016) stated that students are not born with certain attitudes towards physical education lessons, and that these attitudes develop over time due to various variables. Students can develop attitudes towards others at school, as well. In particular, the student's attitudes towards lessons can have an impact on whether they like 
a course and school, their attendance to school, or their academic success. They may develop an attitude towards physical education and sports courses, which contribute to physical, mental, and social development through games (Güllü et al., 2016). In this regard, physical education and sports courses have been subject to various attitude studies both in Turkey and abroad since they have a different structure than other branches in terms of practice and learning outcomes.

In teaching and learning, the opinions of students, who are at the center of the school, teacher and family, regarding their teachers, peers, and the school administration are important. From the perspective of the importance of the study, examining attitudes towards physical education and sports would provide insights with regards to identifying positive and negative opinions on this course and new curricula to be formed. Courses can be made more enjoyable for students by examining these adequately and correcting existing problems. More active participation from students is a desired and wanted outcome. In particular, families should support their children's participation in sports. In this regard, it has been emphasized that this affects self-confidence, cooperation, resilience and socialization levels (Pehlivan, 2009).

Macun et al. (2019) reported that having high levels of self-efficacy perception results in students being more active, resilient, determined, willing and least stressful, while low levels of self-efficacy results in more resistance, reluctance, weakness, and low performance, and that the more self-sufficiency a student has, the more ready he/she will be for an occupation. At the same time, in terms of physical education and sports courses, understanding the way a student perceives himself/herself and his/her belief in himself/herself with regards to self-sufficiency at sports is an important part of the study. Besides, researchers have emphasized that giving positive feedback to students during physical education and sports activities improves their level of self-sufficiency perception, while negative feedback lowers their level of self-sufficiency perception (as cited in Öncü, Feltz, 1988; Bandura, 1994). Analysis of the literature indicates that attitude towards physical education and sports is examined alongside self-sufficiency and these two are interrelated. It has been observed students who see physical education as a game at the same time have positive attitudes towards this course (Balyan et al.,2012; Keskin et al., 2016; Güllü et al., 2016).

This research aimed to analyze attitudes and self-sufficiency perceptions of students from different branches of sports and students without a branch at secondary school level towards the physical education and sports course.

\section{Materials and Methods}

\subsection{Research Model}

This was a descriptive study using the screening model for describing the past or current situation as it is (Kuzu, 2013). Besides, it aimed to explain the incident, individual, or object subject to the research without modifying it and analyze the current condition without changing it (Karasar, 2012). According to Kuzu (2013), the screening model, which is a descriptive study, aims to describe the past or current situation as it is.

Besides, Karasar (2012) describes it as being able to analyze the incident, individual, or object subject to the research under the current condition and without changing it as well as analyzing the current condition without changing it.

\subsection{Study Group}

255 students (120 female, 135 male) studying at two different secondary schools (Vatan secondary school with a sports facility and Ziyaeddin Akbulut secondary school without a sports facility) during the spring semester of the 2019-2020 academic year were included in the study. Among the participants, nine students had a swimming license, 15 had a basketball license, 27 had a football license, 26 had a handball license, 10 had a badminton license, and 168 had no license.

\subsection{Data Collection Tools}

Personal Information Form: This form was developed by the researcher. The form included questions regarding the family profession group, gender, athlete license, age, and independent variables and was at the top of the scale questions.

\subsubsection{Physical Education Predisposition Scale (PEPS)}

The 'Physical Education Predisposition Scale' developed by Hilland et al. (2009) and later adapted to Turkish by Öncü et al. (2015) was employed to identify the participants' attitudes and self-efficacy towards the physical education and sports course. The scale is comprised of 11 items and consists of two factors, namely 'Attitude' (6 items) and 'Self-Efficacy' (5 items). It is a 5-point Likert Type Scale. Response options were listed as "Strongly 
disagree (1)," "Disagree (2)," "Undecided (3)," "Agree (4)," and "Strongly agree (5)," and scores were calculated accordingly. The minimum score that can be obtained from the scale is 11 while the maximum score is 55 . The minimum and maximum scores that can be obtained from the 'Attitude' factor of the scale are 6 and 30, respectively, while the scores for the 'Self-efficacy' factor are 5 at minimum and 25 at maximum. Negative items on the scale are scored in reverse order. In the adaptation of the scale to Turkish, factor structure of the scale exploratory factor analysis $(\chi 2=250.05 ; \mathrm{sd}=43 ; \mathrm{p}<0.01, \mathrm{CFI}=0.94, \mathrm{GFI}=0.95, \mathrm{IFI}=0.94, \mathrm{TLI}=0.93$, SRMR $=0.05$ and RMSEA $=0.07$ ), its reliability is test-retest correlation ( $\mathrm{r}$ Attitude $=0.81, \mathrm{p}<0.01 ; \mathrm{r}$ Self-Efficacy $=0.85, \mathrm{p}<0.01$ ) and Cronbach's Alpha $(\alpha$ Attitude $=0.81, \alpha$ Self Efficacy $=0.84)$ by calculating internal consistency coefficients It has been examined.

\subsection{Data Analysis}

The SPSS 22.0 program was used for the statistical analysis of the data obtained in the study. For each variable (school, gender, athlete license, grade level, age, family profession group), normality analyses were conducted before each analysis, and as the data did not fit the normality assumption, a non-parametric test was used. The Mann-Whitney U Test was performed using the Kruskal-Wallis technique for two or more comparisons.

\section{Results}

In this part of the research; Findings on students' attitudes and self-efficacy towards physical education and sports lesson. The U TEST results for independent groups conducted to examine whether there is a significant difference between the PEPS score averages of the students according to their gender are presented in Table 1.

The results of the U TEST for independent groups conducted to examine whether there is a significant difference between the students' PEPS scores averages according to school type are presented in Table 1.

Table 1. U-Test Results of Attitude and Self-Efficacy Dimensions according to School Variable

\begin{tabular}{|c|c|c|c|c|c|c|}
\hline Factor & $\begin{array}{c}\text { Secondary } \\
\text { School }\end{array}$ & $\mathrm{N}$ & Rank Average & Sum of Ranks & $\mathrm{U}$ & $\mathrm{P}$ \\
\hline \multirow{2}{*}{ Scale Total } & Ziyaeddin & 124 & 122,44 & 15183 & \multirow{2}{*}{7433} & \multirow{2}{*}{0,24} \\
\hline & Vatan & 131 & 133,26 & 17457 & & \\
\hline \multirow{2}{*}{ Attitude } & Ziyaeddin & 124 & 117,17 & 14528 & \multirow{2}{*}{6778} & \multirow{2}{*}{0,021} \\
\hline & Vatan & 131 & 138,26 & 18111 & & \\
\hline \multirow{2}{*}{ Self-Efficacy } & Ziyaeddin & 124 & 129,66 & 16078 & \multirow{2}{*}{7916} & \multirow{2}{*}{0,72} \\
\hline & Vatan & 131 & 126,43 & 16562 & & \\
\hline
\end{tabular}

Table 1 shows the Mann-Whitney $U$ test results of the scores the students received on the physical education and sports predisposition scale. Accordingly, there was a significant difference between Ziyaeddin Akbulut Secondary School and Vatan Secondary School in terms of the total scale dimension. $U=7433, p<0.05$. Attitude dimension scores were $U=6778, p<0.05$. A significant result was found in favor of Vatan Secondary School.

The results of the U TEST for independent groups conducted to examine whether there is a significant difference between the averages of the PEPS scores of the students according to their gender are presented in Table 2 .

Table 2. U-Test Results of Attitude and Self-Efficacy Dimensions according to The Gender Variable

\begin{tabular}{ccccccc}
\hline Factor & $\begin{array}{c}\text { Secondary } \\
\text { School }\end{array}$ & N & Rank Average & Sum of Ranks & U & P \\
\hline \multirow{2}{*}{ Scale Total } & Male & 135 & 138,60 & 18711 & \multirow{2}{*}{6668} & 0,015 \\
& Girl & 120 & 116,07 & 13928 & & \\
\multirow{2}{*}{ Attitude } & Male & 135 & 130,24 & 17582 & 7797 & 0,60 \\
\multirow{2}{*}{ Self-Efficacy } & Girl & 120 & 125,48 & 15057 & & \\
& Male & 135 & 143,34 & 19351 & 6028 & 0,00 \\
\hline
\end{tabular}

Table 2 indicates the Mann-Whitney $U$ test results of the scores they received on the physical education and sports 
predisposition scale. According to this, there was a significant difference between male students and female students in terms of total scale scores. $U=6668, p<0.05$. The self-efficacy dimension scores were $U=6028, p<0.05$. A significant result in favor of male students was determined.

The results of independent groups standard deviation, arithmetic mean, $\mathrm{df}$ and $\mathrm{p}$ values, which were made to examine whether there is a significant difference between the mean scores of PEPS scores of students according to age, are presented in Table 3.

Table 3. KW-Test Results of Attitude and Self-Efficacy Dimensions According to Age Variable

\begin{tabular}{ccccccc}
\hline Faktor & Age & N & Rank Average & Sd & $\mathrm{X}^{2}$ & $\mathrm{P}$ \\
\hline Scale Total & 14 & 7 & 117,00 & 3 & 1,239 & 0,744 \\
& 13 & 71 & 135,44 & & & \\
& 12 & 155 & 126,25 & & & \\
& 11 & 22 & 119,82 & & & \\
Attitude & 14 & 7 & 117,86 & 3 & 0,903 & 0,824 \\
& 13 & 71 & 132,90 & & & \\
Self-Efficacy & 12 & 155 & 127,70 & & & \\
& 11 & 22 & 117,50 & & & 0,97 \\
& 14 & 7 & 115,93 & 3 & & 0,808 \\
& 13 & 71 & 134,80 & & & \\
& 12 & 155 & 125,68 & & & \\
\hline
\end{tabular}

Table 3 indicates the KW test results of the scores they received on the physical education and sports predisposition scale. According to these results, there was no significant difference between the students' age and scale dimensions.

The results of KW-Test conducted to examine whether there is a significant difference in terms of PEPS scores of students according to the family profession group are presented in Table 4.

Table 4. KW-Test Results of Attitude and Self-Efficacy Dimensions according to Family Profession Variable

\begin{tabular}{ccccccc}
\hline Factor & Family Profession & $\mathrm{N}$ & Rank Average & $\mathrm{Sd}$ & $\mathrm{X}^{2}$ & $\mathrm{P}$ \\
\hline Scale Total & Artisan & 103 & 113,46 & 5 & 1,536 & 0,909 \\
& Teacher & 13 & 110,54 & & & \\
& Officer & 52 & 113,63 & & & \\
& Self-Employment & 33 & 125,32 & & & \\
& Engineer & 18 & 120,17 & & & \\
Attitude & Doctor & 10 & 100,40 & & & \\
& Artisan & 103 & 116,21 & 5 & 3,432 & 0,634 \\
& Teacher & 13 & 119,35 & & & \\
& Officer & 52 & 107,88 & & & \\
& Self-Employment & 33 & 129,05 & & & \\
& Engineer & 18 & 112,47 & & & \\
Self-Efficacy & Doctor & 10 & 92,10 & & & \\
& Artisan & 103 & 112,30 & 5 & 0,937 & 0,967 \\
& Teacher & 13 & 108,23 & & & \\
& Officer & 52 & 119,27 & & & \\
& Self-Employment & 33 & 113,65 & & & \\
& Engineer & 18 & 124,64 & & & \\
\hline
\end{tabular}

Table 4 illustrates the KW test results of the scores they received on the physical education and sports predisposition scale. According to these results, there were no significant differences between family professions and scale dimensions.

The results of the KW-Test conducted to examine whether there is a significant difference in terms of PEPS scores of 
the students according to the sports license are presented in Table 3.

Table 5. KW-Test Results of Attitude and Self-Efficacy Dimensions According to Sport License

\begin{tabular}{|c|c|c|c|c|c|c|}
\hline Factor & Sport License & $\mathrm{N}$ & Rank Average & $\mathrm{Sd}$ & $\mathrm{X}^{2}$ & $\mathrm{P}$ \\
\hline \multirow[t]{6}{*}{ Scale Total } & Swimming & 9 & 129,28 & 5 & 38,212 &, 000 \\
\hline & Basketball & 15 & 110,90 & & & \\
\hline & Football & 27 & 169,43 & & & \\
\hline & Handball & 26 & 186,60 & & & \\
\hline & Badminton & 10 & 172,05 & & & \\
\hline & No License & 168 & 111,11 & & & \\
\hline \multirow[t]{6}{*}{ Attitude } & Swimming & 9 & 122,22 & 5 & 29,767 & ,000 \\
\hline & Basketball & 15 & 110,50 & & & \\
\hline & Football & 27 & 153,44 & & & \\
\hline & Handball & 26 & 184,02 & & & \\
\hline & Badminton & 10 & 177,35 & & & \\
\hline & No License & 168 & 114,18 & & & \\
\hline \multirow[t]{6}{*}{ Self-Efficacy } & Swimming & 9 & 135,89 & 5 & 27,070 &, 000 \\
\hline & Basketball & 15 & 117,03 & & & \\
\hline & Football & 27 & 173,22 & & & \\
\hline & Handball & 26 & 169,21 & & & \\
\hline & Badminton & 10 & 154,90 & & & \\
\hline & No License & 168 & 113,31 & & & \\
\hline
\end{tabular}

The data obtained from analysis of Table 5 shows that according to the results of the multiple comparisons made to explain which sports branch caused the difference, in terms of the scale total dimension, there was a significant difference between students engaged in basketball and students engaged in handball, students without a branch and students engaged in handball, and students engaged in football and students without a license.

According to the attitude dimension results, there was a significant difference between students engaged in basketball and students engaged in handball as well as students without a branch and students engaged in handball. According to the results of the self-efficacy dimension, there was a significant difference between students without a branch and students engaged in basketball as well as those without a branch and those engaged in handball.

Table 6 shows the correlation between the attitude and self-efficacy dimensions of students belonging to PEPS.

Table 6. Correlation Results between Scale Dimensions

\begin{tabular}{ccc}
\hline Factor & Attitude & Self-Efficacy \\
\hline \multirow{2}{*}{ Attitude } & 1,000 &, $452^{* *}$ \\
$\mathrm{~N}$ & &, 000 \\
& 255 & 255 \\
Self-Efficacy &, $452^{* *}$ & 1,000 \\
$\mathrm{~N}$ &, 000 & \\
\hline
\end{tabular}

According to the results obtained through the examination of Table 6, there was a positive and significant relationship between self-efficacy and attitude dimensions $(\mathrm{r}=0.452)$.

\section{Discussion and Conclusion}

According to the results of the study, there was a significant difference between Ziyaeddin Akbulut secondary school and Vatan secondary school in terms of the scale total dimension. Attitude dimension scores showed a significant result in favor of Vatan secondary school.

This difference is thought to have been caused by physical education teachers. It is known that teachers have an impact on having positive attitude characteristics. Love and respect for the school and the environment as well as being introduced to them are always mediated through teachers. It is thought that physical education teachers have a 
role in this distinct difference, as it is known that teachers have a crucial role in creating positive attitude characteristics. In fact, children consider teachers as a model due to their interest in the course, which they also see as a game. Therefore, love and respect for the school and the environment as well as being introduced to them are always mediated through teachers (Gürbüz and Sunay, 2005).

In terms of the results of the gender variable, in terms of the scale total dimension, it can be seen that there was a significant difference between male students and female students. In terms of self-efficacy scores, there was again a significant result in favor of male students.

There was no statistically significant variation between individuals' attitudes towards physical education courses based on their gender. Besides, when the schools to which students attended were taken into consideration, there were statistically significant differences between individuals' attitudes towards physical education courses scores based on their gender $(p<0.05)$ (Zengin, 2016). In a study conducted in, Akandere et al. (2010) stated that male students' attitudes towards physical education courses score were higher at a statistically significant level compared to female students. In another study, it was determined that secondary school students' attitudes towards physical education courses were not significantly different between genders; however, there was a significant difference with regards to self-efficacy (Akın et al., 2016). In a study conducted in, Özmutlu et al. (2013; Keskin, Öncü ve Kılıç, 2016) showed that there were significant differences between attitude scores of students with regards to age and gender variables, but there were no significant differences between the attitude scores with regards to family education level and sports branches of students. There were discrepancies between the results obtained in that study and the results obtained in the present study with regards to variables of age, gender, and family education status.

In yet another study, no significant differences were found between secondary school students' attitudes towards physical education courses with regards to variables of gender, age, being a licensed athlete, or engaging in sports regularly $(\mathrm{p}<0.05)$. At the same time, attitudes towards physical education courses were higher in male students compared to female students, students at the age group of 11 compared to students at other age groups, students with sports license compared to students who did not engage in sports, and students who engaged in sports regularly compared to students who did not engage in sports regularly (Cengiz et al., 2018). The results of the study showed that secondary school students' attitudes towards physical education and their self-efficacy were above medium level, there were no differences between male students and female students in terms of their attitudes towards physical education, male students had higher self-efficacy with regards to physical education courses compared to female students, and students' attitudes towards physical education and sports courses and their self-efficacy improved as grade level improved. No statistically significant differences were found based on variables of age, gender, and grade level along with the participants' attitudes towards physical education courses (Sivrikaya and Kılçık, 2018). In their study, Aydoğan et al. (2016) reported that there were no statistically significant differences between self-efficacy perception towards physical education courses of 4th and 5th grade students. In terms of being a licensed athlete, it was found that the happiness level at physical education courses was higher for students who were licensed athletes (Yücekaya, 2020). According to these results, no significant difference was found between these two variables and attitude, self-efficacy, and scale total dimensions with regards to student age and the family profession group variable scores. There were significant differences between students engages in basketball and students engaged in handball, students without a branch and students engaged in handball, and students engaged in football and students without a branch.

In terms of the attitude dimension results, there were no significant differences between students engaged in basketball and students engaged in handball or students without a branch and students engaged in handball. In terms of the self-efficacy dimension results, there were significant differences between students without a branch and students engaged in basketball as well as those without a branch and those engaged in handball. According to correlation test results, there was a positive and significant relationship $(r=0.452)$ between the self-efficacy and attitude dimensions.

Findings obtained from literature research showed that there were differences among other studies in terms of variables such as age, gender, family profession status, licensed athlete status, and sports branches. In that case, according to data obtained from the study conducted, it is possible to deduce that more than one factor impact secondary school students' attitudes towards physical education and sports classes and their perception of self-efficacy. Therefore, it was concluded that no generalization could be made.

It is thought that including the physical education and sports predisposition scale along with factors other than age, gender, school, family profession and similar variables in addition to studies on "Teacher Quality", "School", "Physical Conditions", "Administration", "Peers", "Belonging", and "School Life Quality" in future studies and 
inferencing about their impact would contribute to improving students' predisposition to physical education and sports courses.

\section{References}

Adhikari, P. (2020). Attitude of Female Students Towards Physical Education and Sports. Journal of Balkumari College, 9(1), 65-70. https://doi.org/10.3126/jbkc.v9i1.30088

Akandere, M., Özyalvaç, N. T., \& Duman, S, (2010). Ortaöğretim öğrencilerinin beden eğitimi dersine yönelik tutumları ile akademik başarı motivasyonlarının incelenmesi. Selçuk Üniversitesi Sosyal Bilimler Enstitüsü Dergisi, 24, 1-11.

Akın, N. K., Öncü, E., \& Kılıç, S. K. (2016). Ortaokul Öğrencilerinin Beden Eğitimi Dersine Yönelik Tutum Ve Öz-Yeterlikleri. Spormetre Beden Eğitimi Ve Spor Bilimleri Dergisi, 14(1), 93-108. https://doi.org/10.1501/Sporm_0000000287

Aras, L., \& Asma, M. (2020). Farklı türdeki ortaöğretim kurumlarında okuyan öğrencilerin beden eğitimi ve spor dersine yönelik tutumlarının incelenmesi. Gaziantep Üniversitesi Spor Bilimleri Dergisi, 5(1), 27-39. https://doi.org/10.31680/gaunjss.685547

Atan, T., \& ve İmamoğlu, M. (2016). Ortaöğretim öğrencilerinin beden eğitimi ve spor dersine yönelik tutumlarının çeşitli değişkenler açısından tutumları. Türk Spor ve Egzersiz Dergisi, 18(2), 65-68.

Aydoğan, H., Bardakçı, S., Arslan, E., Civelek, H., \& İşyar, Z. (2016). İlkokul 4.sınıf ve ortaokul 5.sınıf öğrencilerinin beden eğitimi dersine yönelik tutum ve öz-yeterliklerinin incelenmesi. CBÜU Beden Eğitimi ve Spor Bilimleri Dergisi, 11(2), 100.

Balyan, M., Yerlikaya Balyan, K., \& Kiremitçi, O. (2012). Farklı sportif etkinliklerin ilköğretim 2. kademe öğrencilerinin beden eğitimi dersine yönelik tutum, sosyal beceri ve öz- yeterlik düzeylerine etkileri. Selçuk Üniversitesi Beden Eğitimi ve Spor Bilimleri Dergisi, 14(2), 196-201.

Başkonuş, T. (2020). Ortaöğretim öğrencilerinin spora yönelik tutumlarının bazı değişkenlere göre incelenmesi (Kırşehir İli Örneği). Ahi Evran Üniversitesi Sosyal Bilimler Enstitüsü Dergisi, 6(2), 365-376. https://doi.org/10.31592/aeusbed.730674

Cengiz, Ö., Kılıç, M., \& Soylu, Y. (2018). Ortaokul öğrencilerinin beden eğitimi dersine yönelik tutumlarının incelenmesi. Sosyal Bilimler Akademi Dergisi, 1(2), 141-149. https://doi.org/10.38004/sobad.480851

Chung, M. H., \& Phillips, D. A. (2002). The relationship between attitude toward physical education and leisure-time exercise in high school students. Phys Educ, 59(3), 125-138.

Çelik, A. (2018). Orta öğretim düzeyi öğrencilerin beden eğitimi ve spor dersi tutumları: Trabzon İli Örneği. Beden Eğitimi Ve Spor Bilimleri Dergisi, 20(4), 34-42.

Çelik, Z., \& Pulur, A. (2011). Ortaöğretim öğrencilerinin beden eğitimi ve spora ilişkin tutumları. Yüzüncü Yıl Üniversitesi Ĕ̈itim Fakültesi Dergisi, Özel Sayı, 115-121.

Çivril Kara, R. (2018). Yayınlanmamıs yüksek lisans tezi erişim, 14(42). Retrieved from 12 August, 2020 from http://acikerisim.trabzon.edu.tr/xmlui/handle/20.500.12598/223

Deliceoğlu, G. (2018). Ortaokulun ilköğretim öğrencilerinin beden eğitimi ve sporda ölçeklendirmesi. Beden Eğitimi ve Spor Bilimleri Dergisi, 12(1).

Demirhan, G., \& Altay, F. (2001). Lise birinci sınıf öğrencilerinin beden eğitimi ve spora ilişkin tutum ölçeği- II. Spor Bilimleri Dergisi, 12(2), 9-20.

Gouveia, É. R., Ihle, A., Gouveia, B. R., Rodrigues, A. J., Marques, A., Freitas, D. L., ... \& Lopes, H. (2019). Students' Attitude Toward Physical Education: Relations With Physical Activity, Physical Fitness, and Self-Concept. The Physical Educator, 76(4), 945-963. https://doi.org/10.18666/TPE-2019-V76-I4-8923

Güllü, M., Güçlü, M., \& Arslan, C. (2009). Ortaöğretim öğrencilerinin beden eğitimi dersine ilişkin tutumlarının incelenmesi. Sport Sciences, 4(4), 273-288.

Güllü, M., Şarvan C. Ş., Öztaşyonar, Y., \& Kaplan, B. (2016). Ortaokul öğrencilerin beden eğitimi ve spor dersine ilişkin tutumlarının bazı değişkenlere göre incelenmesi (Şanlıurfa İli Örneği). Gaziantep Üniversitesi Spor Bilimleri Dergisi, 1(2), 49-61. 
Gürbüz, A., ÖZKAN, H., \& Gürbüz, A. (2012). Ortaokul öğrencilerinin beden eğitimi ve spor dersine yönelik tutumlarının belirlenmesi. (Muğla örneği). Pamukkale Spor Bilimleri Dergisi, 3(2), 78-89.

Gürbüz, P., \& Sunay, H. (2005). Beden eğitimi ve spor öğretmeni adaylarının tutumları (Ankara ili örneği). Eğitim ve Bilim, 30(137), 27-37.

Hilland, T. A., Stratton, G., \& Vinson, D. (2009). The physical education predisposition scale: preliminary development and validation. Journal of Sport Sciences, 27(14), 1555-1563. https://doi.org/10.1080/02640410903147513

Hünük, D., \& Demirhan, G. (2003). İlköğretim sekizinci sınıf, lise birinci sınıf ve üniversite öğrencilerinin beden eğitimi ve spora ilişkin tutumlarının karşılaştırılması. Spor Bilimleri Dergisi, 14(4), 175-184.

Kagıtcıbasi, C. (2005). New Human and People. Istanbul: Evrim Publisher.

Karasar, N. (2012). Bilimsel Araştırma Yöntemi. Ankara: Bilim Kitap Kırtasiye Yayınevi.

Keskin, N., Öncü, E., \& Küçük, K. (2016). Ortaokul öğrencilerinin beden eğitimi dersine yönelik tutum ve öz-yeterlikleri. Spormetre Beden Eğitimi ve Spor Bilimleri Dergisi, 14(1), 93-107. https://doi.org/10.1501/Sporm_0000000287

Koçak, B., Macun, B., \& Safalı, S. (2019). Öğretmen adaylarının öğretmen özyeterlik inanç düzeyleri ile iş hayatına hazır bulunuşluklarının incelenmesi. Uluslararası Türkçe Edebiyat Kültür Eğitim (TEKE) Dergisi, 8(1), 549-567. https://doi.org/10.7884/teke.4409

Kuzu, A. (2013). Bilimsel araştırma yöntemleri. In A. A. Kurt (Ed.), Veri toplama yöntem araçlarl, 95-118. Eskişehir: Anadolu Üniversitesi.

Marttinen, R., Fredrick III, R. N., \& Silverman, S. (2018). Changes in student attitude toward physical education across a unit of instruction. Journal of Physical Education and Sport, 18(1), 62-70.

Orlić, A., Mijatović, J., \& Lazarević, D. (2018). Sociodemographic and psychological characteristics of students as predictors of their attitude toward physical education. Fizička kultura, 72(2), 161-169. https://doi.org/10.5937/fizkul18021610

Öncü, E., Gürbüz, B., \& Küçük, K. S., (2015). Psychometric properties of the Turkish version of the physical education predisposition scale. 179. In İ. Önder (Ed.), ERPA International Health and Sports Science Education Congress, ERPA, Athens.

Özmutlu, İ., Sivrikaya, A. H., Gürkan, A. C., \& Dalkılıç, M. (2013). An Investigation Into Secondary School Students' Attıtudes Towards Physical Education and Sports Lessons (The Example of Kars Province). International Journal of Academic Research Part B, 5(3), 52-57. https://doi.org/10.7813/2075-4124.2013/5-3/B.9

Pehlivan, Z. (2009). Spora katılan çocuklara yönelik ailelerin beklentileri, çocuklarda gözlenen davranış değişimleri ve spora katılımın önündeki engeller. Spormetre Beden Eğitimi ve Spor Bilimleri Dergisi, 7(2), 69-76. https://doi.org/10.1501/Sporm_0000000152

Scrabis-Fletcher, K., Rasmussen, J., \& Silverman, S. (2016). The relationship of practice, attitude, and perception of competence in middle school physical education. Journal of Teaching in Physical Education, 35(3), 241-250. https://doi.org/10.1123/jtpe.2015-0129

Silverman, S. (2017). Attitude research in physical education: A review. Journal of Teaching in Physical Education, 36(3), 303-312. https://doi.org/10.1123/jtpe.2017-0085

Silverman, S., \& Subramaniam, P. R. (1999). student attitude toward physical education and physical activity: a review of measurement 1ssues and outcomes. Journal of Physics Teacher Education, 19, 96-124.

Sivrikaya, Ö., \& Kılçık, M. (2018). Farklı illerdeki ortaokul öğrencilerinin beden eğitimi dersine karşı tutumlarının ölçülmesi. Spor ve Performans Araştırmaları Dergisi, 9(3), 162-173. https://doi.org/10.17155/omuspd.399584

Sunay, H. (1998). Spor eğitimi alt yapısında beden eğitimi öğretmeni ve antrenörün önemi. Beden Eğitimi ve Spor Bilimleri Dergisi, 3(3), 43-50.

Togo, O. T., Caz, C., \& Kayhan, R. F. (2018). The relationship between resilience and constant hope in students studying sports science. European Journal of Educational Research, 6(4), 583-589. https://doi.org/10.12973/eu-jer.7.3.583 
Uğraş, S., \& Özen, G. (2020). Beden eğitimi dersine yönelik tutum ile okula aitlik arasındaki ilişkinin incelenmesi. Fiziksel Kültür ve Spor Pedagojisi, 24(1), 48-53.

Yücekaya, M. (2020). Ortaokul öğrencilerinin beden eğitimi ve spor dersi mutluluk düzeylerinin incelenmesi. Uluslararası Dağcllık ve Tırmanış Dergisi, 3(1), 27-37. https://doi.org/10.36415/dagcilik.745302

Zengin, S., Hekim, M., \& Hekim, H. (2016). Ortaokul ve lise öğrencilerinin beden eğitimi dersine yönelik tutumlarının cinsiyet ve öğrenim kademesi değişkenine göre incelenmesi. Journal of Human Sciences, 13(2), 3242-3251. https://doi.org/10.14687/jhs.v13i2.3944

\section{Copyrights}

Copyright for this article is retained by the author(s), with first publication rights granted to the journal.

This is an open-access article distributed under the terms and conditions of the Creative Commons Attribution license (http://creativecommons.org/licenses/by/4.0/). 